\title{
Critical Thinking Activities through Reasoning Tasks towards Cognitive Achievements
}

\author{
Sigit Dwi Saputro ${ }^{1,2, *}$, Tukiran ${ }^{1}$, Zainul Arifin Imam Supardi ${ }^{3}$, Neelur Rohmah ${ }^{2}$, Ninik Setyawati ${ }^{4}$, \\ Rizal Faozi ${ }^{5}$ \\ ${ }^{1}$ Postgraduate Program, Universitas Negeri Surabaya, 60213, Surabaya, Indonesia \\ ${ }^{2}$ Faculty of Education, University of Trunojoyo, 69162, Bangkalan, Indonesia \\ ${ }^{3}$ Department of Physics, Universitas Negeri Surabaya, 60213, Surabaya, Indonesia \\ ${ }^{4}$ Informatics Management, Mitra Karya Mandiri Polytechnic, 52263, Brebes, Indonesia \\ ${ }^{5}$ Postgraduate Program, Semarang State University, 50275, Semarang, Indonesia
}

Received October 13, 2020; Revised December 4, 2020; Accepted December 13, 2020

\section{Cite This Paper in the following Citation Styles}

(a): [1] Sigit Dwi Saputro, Tukiran, Zainul Arifin Imam Supardi, "Critical Thinking Activities through Reasoning Tasks towards Physics Cognitive Achievements," Universal Journal of Educational Research, Vol. 8, No. 12B, pp. 8149-8158, 2020. DOI: 10.13189/ujer.2020.082618.

(b): Sigit Dwi Saputro, Tukiran, Zainul Arifin Imam Supardi (2020). Critical Thinking Activities through Reasoning Tasks towards Physics Cognitive Achievements. Universal Journal of Educational Research, 8(12B), 8149-8158. DOI: 10.13189/ujer.2020.082618.

Copyright $\bigcirc 2020$ by authors, all rights reserved. Authors agree that this article remains permanently open access under the terms of the Creative Commons Attribution License 4.0 International License

\begin{abstract}
Learning in principle is building one's reasoning process. Textbooks used as learning media for students are often helpless in training their thinking skills. One way to help students' reasoning process is critical thinking activities through reasoning tasks, aiming to achieve the learning objectives. The purpose of this study is to determine the cognitive achievement based on KKM (Minimum Completeness Criteria), and the classical completeness of critical thinking through reasoning tasks in physics learning. This research is quantitative, with an ex post facto design method. The research was conducted at Islamic Senior High School (MAN) 1 Bangkalan from a population of 125 students, and then 33 of students were selected as samples. The research instruments used were questionnaire and cognitive achievement test. The result of the questionnaire about understanding the material concept with a percentage level of $80 \%$ means that students have a very good understanding. The learning achievements of students' cognitive achievement are able to exceed the minimum completeness criteria, but unable to achieve classical completeness.
\end{abstract}

Keywords Critical Thinking, Reasoning Tasks, Cognitive Achievement

\section{Introduction}

Physics is a subject that deals with facts and events around us [1]. The objective of learning physics at high school level is that students are able to develop skills, attitude, scientific values, and master scientific concepts [2]. Thus, in learning physics, students do not only memorize but should be able to have thinking skills to understand a certain fact or event [3]. The impact of applying the thought process in student learning will gain a deep understanding [4].

Based on the Focus Group Discussion of the Education Working Group of Trunojoyo Madura University, there are some problems experienced by teachers in Madura, such as 1) textbooks are the main learning resource for teachers in delivering subject matter; 2) the teachers do not train students to solve problems contextually because they only adapt the materials from the textbook. Learning resource such as textbook is included in the category of weak in instilling a concept and analyzing problems [5]. Textbooks only contribute 29.4 percent to shaping scientific literacy thinking, or do not facilitate students to deal with authentic problems and scientific methods of thinking [6]. Therefore, the textbooks had by students still have lack contribution to the students' thinking skills. 
The importance of critical thinking skills in the learning process makes teachers need to prepare learning materials well. In addition to textbooks, additional activities are required. One of which is assignment. Assignment is an important element in learning. The benefit of assignments is that it can increase the focus of attention on the subjects studied by students thus they can improve critical thinking skill [7].

\subsection{Instructional Task}

Giving assignments is part of learning through activities designed to accommodate individual differences among students [8]. Tasks are jobs that involve students in understanding, manipulating, producing, or interacting with other friends through communication language that optimizes each of ability with the aim of being able to complete the task [9].

Structured assignment instructions which pay attention to differences between students can be done through assignment design that looks at the student's background, learning motivation, and the abilities of each student [10].

The task must also have optimal difficulty level. The task should not be too easy or too difficult. It should be adjusted to the level of students' ability. At the same time, the task can be in form of problems that are often faced by students thus they can think about how to resolve those problems [11]. Therefore, it can be said that task is problem-solving oriented activities.

The task must include several criteria to be considered as the first task. It must have a meaningful goal $[12,13]$. An assignment is not just a question that must be completed by students, but it can benefit students after doing the assignment. Another criterion is that assignments given to students must have clear results. In other words, each student or group has results that can be shown to others $[14,13]$.

Each task requires problem-solving skills with different difficulty level. Task instructions are usually difficult to understand. One strategy to reduce student difficulty in understanding the task instructions is to use multimodal instructions [15]. One of the multimodal instructions used is a presentation that displays visual-audio or audio-visual effects, such as watching a certain video recording. It aims to focus students' attention on the tasks that will be delivered [16].

Every educator needs to pay attention whether each given task is focused on the goals that have been set. A good task must be structured especially for skills-oriented learning [17]. Through assignments, students will get used to focus on understanding a command, or students will ignore activities outside the assignments given [18]. Thus students will only find learning resources that are relevant to the instructions in the assignment [19].

The given task is expected to optimize students' thinking skills that are tailored to the purpose of learning.
The complexity of learning objectives requires a clear division of task instructions [20]. Therefore, task instruction gives a thinking effect to each student to act effectively in order to be able to complete the task precisely based on the target.

Giving assignments is useful for students to show various knowledge such as procedural knowledge, meta-cognitive knowledge, psychomotor and even in the affective domain [21]. The effect of giving specific assignments has an important role in learning achievement due to student-centered learning. Students need a set of information to be able to complete each task given by the teacher.

Therefore, the given task will provide each student an opportunity to be active in the learning process. Students collaborate with each other, share information, find solutions, and explore alternatives until they can complete the task $[22,13]$. The use of assignments has a positive influence on student group work when they share ideas and negotiate collaboratively. Finally, working in groups reduces the anxiety experienced by students. This is because students can help each other, share different ideas, complement each other's strengths and weaknesses, and finally the task can be easily done [14].

The effect of given task increases someone's thinking skill and creativity [23]. There are two learning designs to improve students' thinking skill and creativity. First, each assignment instruction is expected to provide direction to evaluate an object that is being studied [24]. Second, assignments can stimulate students' creativity through optimizing the ideas they have to produce a product that is better than the previous [25].

Assignment has an impact on achieving learning goals well [26]. Even task instruction explicitly affects the results of achieving complex learning goals with results that are accurate or in accordance with the targets set [27]. By giving a certain task, it will have an impact on improving learning achievements [28]. Giving assignments requires students' liveliness so that the information obtained is more in-depth and meaningful [29].

Based on the explanation, assignment can be defined as part of learning designed to involve the concept of understanding, manipulating, producing and interaction among students. Assignments can be in form of contextual problems that need to be solved by students. Assignments can be useful for developing critical thinking skills and improving learning achievements.

\subsection{Critical Thinking Activities through Reasoning Task}

One of the important thinking skills that students must have in the 21st century is critical thinking skill [30]. In a critical perspective in testing one's own thinking, it also puts forward the ability to think rationally based on 
evidence [31]. Critical thinking is a type of thinking that is oriented towards a person's rational answers to certain goals [31, 31]. So it can be concluded that critical thinking skill is the ability of students to argue both verbally or in writing rationally based on evidence.

Critical thinking indicators have been formulated by educational experts such as types of decisions in the form of formulating hypotheses, questions, alternatives, and activity plans [33]. Another opinion, Halpern [34] stated that the indicators can be formulating conclusion, calculating possibilities, making decisions, and solving problems. A person's cognitive skills include analysis, interpretation, evaluation, conclusion, explanation, and regulation [32].

One of the task designs that can develop critical thinking skill is reasoning task [35]. The reasoning task strengthens the understanding that students already have. Students are expected to be able to connect various concepts to answer phenomena that occur in everyday life. For example, they think of how many times we are advised to do sports in one week [36]. In line with that understanding, in reasoning task, it is not just memorizing but it involves a conceptual understanding that is analyzed proportionally [37].

The reasoning task has a proportion problems stage and the next stage is comparison problems. Comparison problems will not be maximal if we have not mastered the proportion problem stage [38]. Proportion problems are divided into several types. They are rates, similarity, mixtures, and part-part-whole [37]. Senior high schools are capable at the rates and similarity stages and experience difficulties in the mixtures stage.

Based on the explanation regarding critical thinking, the learning activities chosen Facione [32] are analysis, interpretation, evaluation, conclusion, explanation and self-regulation. The selection is due to reasoning tasks require activities that are not just memorizing but require higher order thinking skill so that these indicators are very appropriate to be applied for this research.

\subsection{Cognitive Learning Achievement}

Measuring student learning achievement is an important part of the world of education, to determine the achievement of learning objectives [39]. With the measurement of learning achievements, it will be able to evaluate both teachers and students [40]. The teacher as a learning designer, of course, will be evaluated for the learning design, while students will receive information on their development.

Learning objectives will be evaluated both in detail for each individual and an overview through several samples that are asked questions by the educators [39]. Meanwhile, the knowledge can be measured through formal evaluation of learning either through midterm or final semester exams.
The completeness of learning achievements is a minimal level of achievement of attitude competencies, knowledge competencies and skills competencies which include completeness of mastery of substances and mastery of learning in the context of learning period [41]. Learning outcome is classified into three domains. They are cognitive domain, affective domain and psychomotor domain. Learning outcome is only measured in the cognitive domain. According to Bloom, all efforts related to brain activity are included in the cognitive domain. The cognitive domain contains six levels of thought processes, from the lowest level to the highest level. The six levels are: remembering, understanding applying, analyzing, evaluating and creating [42]. The cognitive domain is used as a research target to measure student success.

Completeness is divided into two things. They are 1) minimum completeness criteria (KKM). It is learning completeness based on comparison to the minimum average score and 2) classical completeness (KL). It is the percentage of students in one class who have reached the standard KKM that has been set. The purposes of this study are to determine 1) the achievement of KKM in students' cognitive learning achievement in the application of critical thinking through reasoning task design; and 2) the achievement of students' classical completeness (KL) cognitively in the application of critical thinking through reasoning task design.

\section{Materials and Methods}

\subsection{Research Design}

This study used an Ex post facto design, which measures student achievement after giving treatments in the form of critical thinking activities through reasoning tasks. The population in the study consisted of 4 classes with a concentration of science with a total of 125 students at Islamic Senior High School 1 Bangkalan. A sample of 33 students had fulfilled $20 \%$ of the population [43]. The material taught in physics learning is the measurement of length, time, mass and temperature.

\subsection{Instruments}

\subsubsection{Questionnaire}

The questionnaire was designed to determine the response of students' understanding which consists of 4 questions a) the ease of language b) the ease of understanding of pictures c) the ability to increase learning motivation d) the ability to increase understanding of concepts. The questionnaire was distributed at the end of the lesson before the measurement process of the cognitive learning achievement test 


\subsubsection{Questionnaire}

The test was used to measure students' cognitive learning achievements in the form of multiple choices consisting of 10 questions selected in the textbook which are assumed to be valid; this is because the book is an official release by the Ministry of Education and Culture [44]. As for the distribution of cognitive abilities, they are applying (C3) as many as 4 questions, analyzing (C4) as many as 3 questions and evaluating (C5) as many as 3 questions. Cognitive learning achievement test was conducted after the application of critical thinking activities through reasoning tasks.

\subsection{Procedures}

This research contains four stages of activities. They are the introduction to learning, the main activity that is the implementation of critical thinking activities through reasoning tasks, closing and evaluation of learning achievements.

\subsubsection{Introduction to learning}

Activity served to focus students' attention on learning. Furthermore, the teacher conveyed the learning objectives, they are 1) students can apply the concept of measurement in everyday life, and 2) students can analyze the variation of measurements of length, mass, and temperature. The next stage was the formation of groups consisting of 4-5 students who had been determined by the teacher with consideration of gender and student cognitive differences. Each group studied the textbook then given 4 reasoning tasks which included length, time, mass and temperature.

First, reasoning task on length material, which contains the context of the game "kites". In the scenario of the assignment, students are asked to predict which kite will fly the highest if the number of rolls with different tube diameters is different. The second reasoning task on mass material, measuring mass, the reasoning task contains mass conversion. In the scenario, there are three barbells = the first is 21 ounces, the second is 4 pounds and the third is $3 \mathrm{~kg}$. Students are asked to sort them from the lightest to the heaviest.

The third reasoning task in the material of time contains the context of frog jumping. Students are asked to analyze which frog will finish first if the rhythm of the frog's jumping length and time is different. Fourth, temperature measurement, the reasoning task contains temperature conversion. Students are asked to look for the lowest and highest temperatures if the measurement results are measured with a temperature measuring instrument Fahrenheit $194^{\circ}$, Celsius $95^{\circ}$, Reaumur $78^{\circ}$ and Kelvin $365^{\circ}$.

\subsubsection{Critical thinking activities through reasoning task}

The indicators of learning activities selected in Critical Thinking are analysis, interpretation, evaluation, conclusion, explanation and self-regulation is presented in (Figure 1). While the activity chart includes:

1. Students read and understood the reasoning task. This activity includes critical thinking activities on the Analysis and Interpretation indicators. Students were asked to analyze each question contained in the reasoning task, what variables are contained in the question and how are the relationships between these variables. Students were asked to interpret the meaning of the reasoning task which contains images such as questions on the subject of measuring length and temperature.

2. The members of the team in the group arranged strategies so that the reasoning task could be done correctly and did not exceed the predetermined time. Each individual worked on the results of group decisions by optimizing learning resources such as textbooks and also peers in this activity to practice self-regulation.

3. Each group made a decision to answer the reasoning task. Each student's question was asked to provide conclusions that are tailored to the material for measuring length, mass, time, and temperature. This activity trains the rest to do inference.

4. Each group checked the work of the other groups. This learning activity trains each individual in the group to have evaluation skill.

5. Student representatives presented the results of the evaluation of the other groups' work. This learning activity trains explanation skills in which students explained the results of group's work in front of other groups. This activity also trains students' interpretation skills so that they can make graphics or pictures to make it easier to explain.

\subsubsection{Closing}

The closing activity of learning was done when the teacher provided the opportunity for students to ask questions according to the material that had been discussed. The teacher reflected on the learning process that had been taking place, and reinforced the concept of the material that had been discussed. The teacher gave questions orally to some students, to measure the understanding that had been given.

\subsubsection{Evaluation of learning achievements}

The learning evaluation activity was carried out outside the student learning hours by providing students' understanding questionnaires and also cognitive tests. This activity was carried out by telling all students regarding the time and place of implementation. This activity aims to measure learning achievement after implementing critical thinking activities through reasoning tasks. Student learning achievements are compared with two targets, they are the minimum 
completeness criteria with a score of 75 and classical completeness of $75 \%$.

\subsection{Data Analysis}

After students had received critical thinking activities through reasoning tasks, their understanding was measured through a questionnaire. The quantitative calculation is done by dividing the scores that have been obtained compared to the maximum as shown in equation $1[45]$.

$$
\text { Response }=\frac{\text { Obtained Score }}{\text { Maximal Score }} \times 100 \%
$$

The results of the percentage of responses are then categorized as (Table 1) [46].
Table 1. Analysis of Students' Understanding Questionnaire Results

\begin{tabular}{|c|c|}
\hline Calculation Results & Criteria \\
\hline $80 \%<\mathrm{H} \leq 100 \%$ & Very Good \\
\hline $60 \%<\mathrm{H} \leq 80 \%$ & Good \\
\hline $40 \%<\mathrm{H} \leq 60 \%$ & Enough \\
\hline $20 \%<\mathrm{H} \leq 40 \%$ & Bad \\
\hline $0 \%<\mathrm{H} \leq 20 \%$ & Very Bad \\
\hline
\end{tabular}

The learning achievement questionnaire data were analyzed quantitatively, which is a way to manage data by systematically compiling it in the form of numbers, data or percentages [47]. The calculation of the KKM in the study was done by comparing the class average with the specified KKM value that is 75 . The calculation of classical completeness is calculated by equation 2 .

Classical Completeness $=$ The number Students who reach the KKM

The total number of students

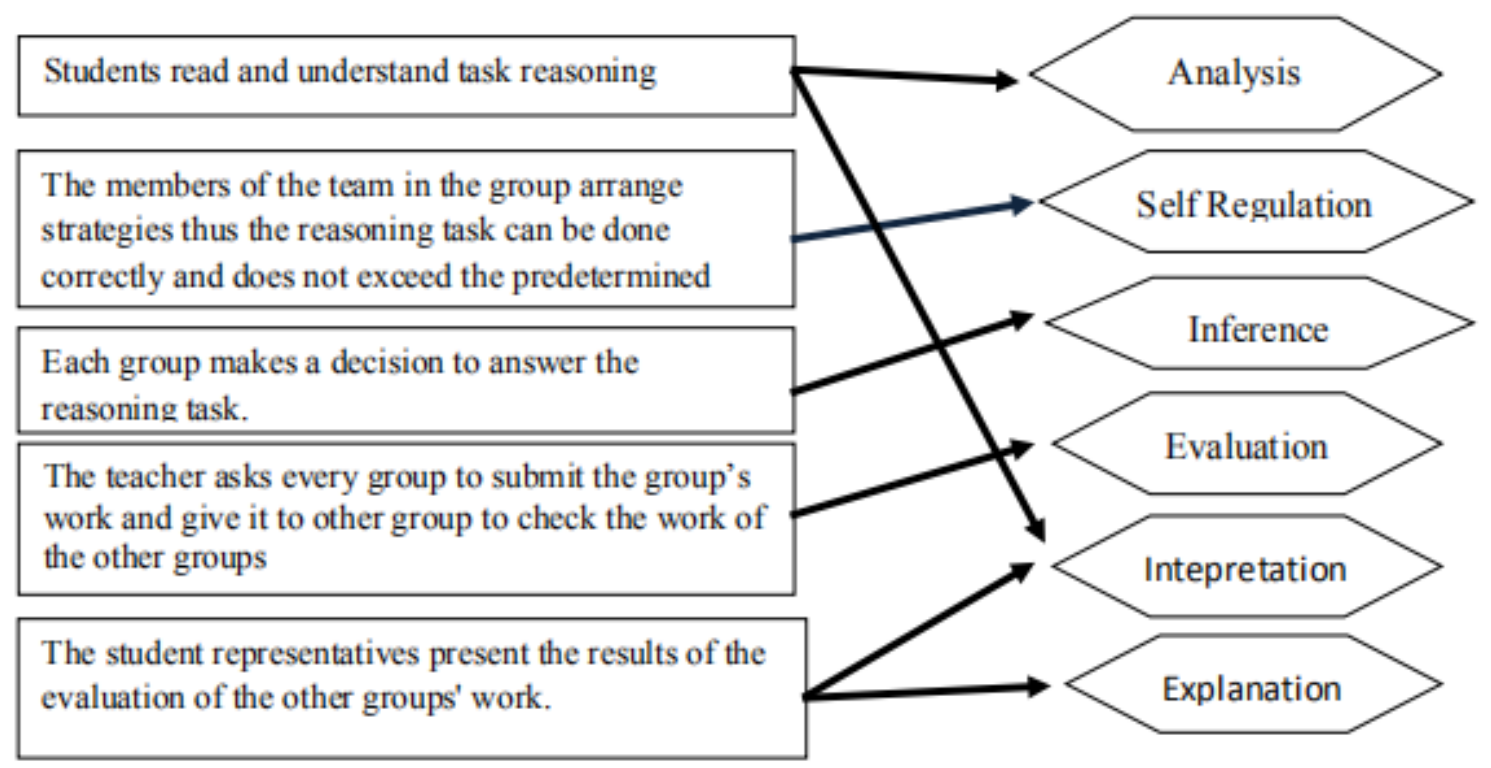

Figure 1. Critical Thinking Activities through Reasoning Task learning Activities Process 


\section{Findings}

The data collected in the study include: students' understanding questionnaire responses data and cognitive learning achievement tests. Students' understanding responses were obtained from the results of questionnaire calculations and student achievement analysis through the test results of the number of students as many as 33 .

\subsection{Understanding Response Questionnaire Data}

This data were obtained through a questionnaire on student understanding responses. A total of 33 students filled out their response questionnaires related to critical thinking activities through reasoning tasks on understanding the material on a) the ease of language b) the ease of understanding of pictures c) the ability to increase learning motivation $\mathrm{d}$ ) the ability to improve understanding of concepts is presented in (Table 2).

Table 2. Student Understanding Responses

\begin{tabular}{|c|c|c|c|c|}
\hline No. & $\begin{array}{c}\text { The element of } \\
\text { understanding }\end{array}$ & $\begin{array}{c}\text { Score } \\
\text { obtained }\end{array}$ & $\begin{array}{c}\text { Maximum } \\
\text { score }\end{array}$ & $\begin{array}{c}\text { Percentage } \\
(\%)\end{array}$ \\
\hline 1 & Ease of language & 109 & 132 & 82.5 \\
\hline 2 & $\begin{array}{c}\text { Ease of } \\
\text { drawing/picture }\end{array}$ & 105 & 132 & 79.5 \\
\hline 4 & $\begin{array}{c}\text { Increase the } \\
\text { motivation to } \\
\text { learn }\end{array}$ & 104 & 132 & 78.8 \\
\hline $\begin{array}{c}\text { Improve the } \\
\text { understanding of } \\
\text { concept }\end{array}$ & 104 & 132 & 78.8 \\
\hline \multicolumn{2}{|c|}{ Total } & 422 & 528 & 80 \\
\hline
\end{tabular}

In Table 2, based on the results of the calculation of the questionnaire, the percentage of language ease indicators in reasoning Tasks is $82.5 \%$, the ease of understanding of pictures is $82.5 \%$, the ability to increase learning motivation is $78.8 \%$, and the ability to improve understanding of concepts is $78.8 \%$

Based on the filling questionnaire summarized in Table 2 , the percentage level of students' understanding in using critical thinking activities through reasoning task can be calculated at 422 , while the maximum score obtained is 528. Thus, it can be calculated by this equation:

$$
\text { Response }=\frac{\text { obtained Score }}{\text { Maximal Score }} \times 100 \%
$$

Then, it can be calculated as below:

$$
\text { Response }=\frac{422}{528} \times 100 \%=80 \%
$$

Thus, students' understanding of the use of reasoning tasks is included in the good category.

\subsection{Cognitive Learning Achievement Data}

These data were obtained through student achievement tests. The presentation is made in the histogram figure 2 as follows. (Figure 2) can describe that only 1 student got a score of 50 with a percentage of $1 \%, 3$ students got a score of 60 with a percentage of $10 \%, 7$ students got a score of 70 with a percentage of $21 \%, 11$ students got a score of 80 with a percentage $33 \%$, and 11 students got a score of 90 with a percentage of $33 \%$.

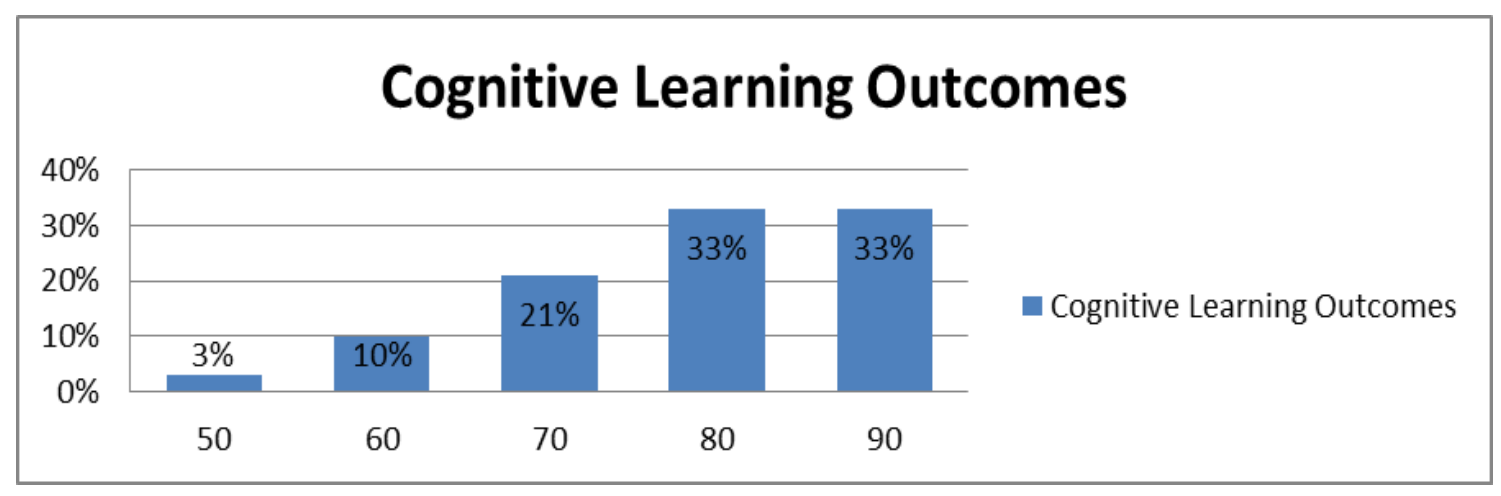

Figure 2. A Histogram of cognitive achievement achievements 
Table 3. Distribution of cognitive learning achievements

\begin{tabular}{|c|c|c|c|c|c|c|}
\hline No. & Cognitive Domain & $\begin{array}{l}\text { Question } \\
\text { Number } \\
\end{array}$ & Correct & False & $\begin{array}{c}\text { Percentage of correctness of } \\
\text { each question }(\%)\end{array}$ & $\begin{array}{l}\text { Percentage of correctness of } \\
\text { each cognitive domain }(\%)\end{array}$ \\
\hline 1 & \multirow{4}{*}{ Applying (C3) } & 1 & 33 & 0 & 100 & \multirow{4}{*}{100} \\
\hline 2 & & 3 & 33 & 0 & 100 & \\
\hline 3 & & 8 & 33 & 0 & 100 & \\
\hline 4 & & 10 & 33 & 0 & 100 & \\
\hline 5 & \multirow{3}{*}{ Analyzing (C4) } & 2 & 28 & 6 & 82 & \multirow{3}{*}{80} \\
\hline 6 & & 4 & 33 & 0 & 100 & \\
\hline 7 & & 6 & 19 & 14 & 58 & \\
\hline 8 & \multirow{3}{*}{ Evaluating (C5) } & 5 & 26 & 7 & 78 & \multirow{3}{*}{54} \\
\hline 9 & & 7 & 8 & 25 & 24 & \\
\hline 10 & & 9 & 19 & 14 & 52 & \\
\hline
\end{tabular}

The distribution of good cognitive learning achievement which includes Applying (C3), Analyzing (C4) and Evaluating (C5) which has been measured is summarized in table 3 .

Based on the table 3 , the correctness of students in answering questions in the Applying domain (C3) reaches $100 \%$, the Analyzing domain (C3) reaches $80 \%$ and the evaluating domain $(\mathrm{C} 4)$ reaches $54 \%$. It shows that the higher the cognitive domain, the lowest the student's level of correctness or the students find it more difficult to do the questions.

\subsubsection{Minimum Completeness Criteria of Cognitive Learning Achievement}

The description of the learning outcome data presented includes the comparison of the class average with the KKM and classical completeness is presented in (Table 4).

Table 4. Minimum Completeness Criteria of Cognitive Learning Achievement

\begin{tabular}{|c|c|c|c|c|c|}
\hline \multirow{2}{*}{ KKM } & \multicolumn{5}{|c|}{ Learning Achievements Average } \\
\cline { 2 - 6 } & $\begin{array}{c}\text { The } \\
\text { Amount } \\
\text { of Data }\end{array}$ & Max. & Min. & Average & $\begin{array}{c}\text { Standard } \\
\text { Deviation }\end{array}$ \\
\hline 75 & 33 & 90 & 50 & 78.48 & 10.9 \\
\hline
\end{tabular}

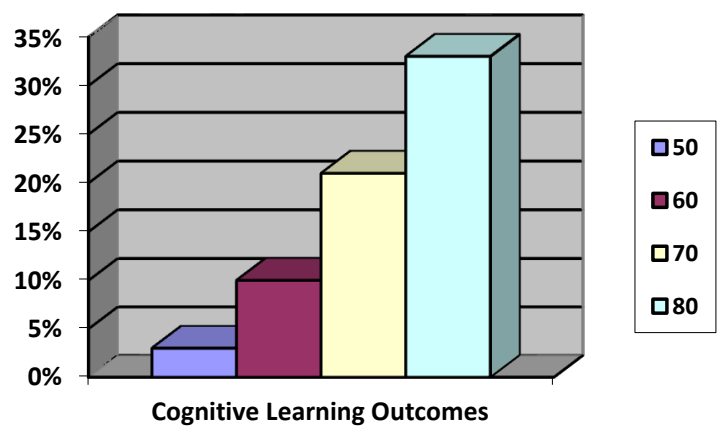

In (Table 4), it can be explained that the highest learning outcome is 90 , while the lowest score is 50 , the average score is 78.48 and the standard deviation is 10.9 . It shows that the average value after using critical thinking activities through reasoning tasks is higher than the KKM.

\subsubsection{Classical Completeness of Cognitive Learning Achievement}

The classical completeness of learning achievements in the use of critical thinking activities through reasoning tasks is summarized in (Table 5).

Table 5. Number of Students Achieving the Minimum Completeness Criteria (KKM)

\begin{tabular}{|c|c|c|}
\hline No. & Student Completeness & Amount \\
\hline 1 & Achieving KKM & 22 \\
\hline 2 & Not Achieving KKM & 11 \\
\hline \multicolumn{2}{|c|}{ Total } & 33 \\
\hline
\end{tabular}

The classical completeness results of cognitive achievement can be calculated by the equation:

Then, it can be calculated as below:

$$
\begin{gathered}
\text { Classical Completeness = } \\
\frac{\text { The number Students who reach the KKM }}{\text { The total number of students }} \times 100 \%
\end{gathered}
$$

Then, it can be calculated as below;

$$
\text { Classical Completeness }=\frac{22}{33} \times 100 \%=67 \%
$$

Based on (Table 5), it obtains the level of completeness of learning achievements in using critical thinking activities through reasoning tasks that had been tested from 33 students. There are 22 students who achieve the KKM with a percentage rate of $67 \%$ while 11 students do not achieve the KKM with a percentage rate of $33 \%$. Although the average student learning achievements are able to exceed the KKM score, students who have not completed are still in the high category which is $33 \%$. 


\subsection{Discussion}

The purpose of this study is to determine cognitive achievement in critical thinking activities through reasoning tasks. Student learning activities use textbooks and reasoning tasks which consist of material of measuring length, time, mass and temperature. In order to facilitate the understanding process and critical thinking process, 7 groups were formed with 4-5 members. In addition, the process of interaction in discussions and answers strongly supports critical thinking skills.

\subsubsection{Achievement of the Minimum Completeness Criteria}

The results of the questionnaire responses to students understanding show positive results with the percentage level of understanding of $80 \%$. The results of these calculations are categorized as very good category [46]. The results of the questionnaire are in line with the completeness of student achievement. From the students' achievement outcome, it obtained the average score of 78.48. Thus, it can be concluded that students have exceeded the target score or KKM set by the teacher.

Based on those two criteria, the result of students' understanding questionnaires with the percentage rate of $82 \%$ which means that the category has a very good understanding is in line with the result of student cognitive achievement which is more than the target KKM with the average score of 78.48. Thus the application of critical thinking activities through reasoning tasks can achieve the ultimate goal of learning in the KKM category.

These findings confirm previous research that is the achievement of predetermined learning objectives [26]. Even task instructions explicitly affect the results of achieving goals according to the targets set [27]. By giving certain tasks, it will have an impact on improving learning achievements [28].

Through assignments students will get used to focus on understanding a command, or students will ignore activities outside of the assigned task [18]. Thus students will only find learning resources that are relevant to the instructions in the assignment [19].

The interaction between students to immediately complete tasks that occur in class also confirms the research [14]. Students exchange thoughts and ideas to complete the task $[22,13]$. In addition, it strengthens Beattie's [21] research results that assignment has an impact on affective aspects, which is shown by respecting other's opinions and argue in a good way.

By giving assignments, students are expected to optimize their thinking skills that are tailored to the purpose of learning. The complexity of the learning objectives requires a clear division of task instructions [20]. Thus, task instruction gives a thinking effect to student to act effectively, allowing them to complete the task precisely according to the target.

\subsubsection{Achievement of Classical Completeness Criteria}

Based on the calculation of class completeness in the application of critical thinking activities through reasoning task, it does not achieve the expected classification completeness goal, in which $75 \%$ of students have a score above the KKM average. The results of the classical completeness study reached $67 \%$, which means that $8 \%$ of students still need to be able to achieve the classical completeness target.

This classical incompleteness occurs because the students are less able to complete the cognitive test on the evaluating domain (C5). The level of students' correctness only reached $54 \%$ or half of the students are unable to answer the questions. The concept of evaluation in the learning process does not give students the opportunity to evaluate the basic concept. Students only see the work of other groups who have tried to do the task optimally. In the field, there was no significant evaluation regarding misconceptions, only punctuation errors and symbol usage.

The researchers focused on interactions between students through the formation of groups of 4-5 small students with the aim of the student scaffolding process in achieving maximum knowledge [48]. Ignoring assignments that are scaffolding tasks, that is making tasks according to the various cognitive abilities of students [49]. Each group was given the same task regardless of the group's ability level, this is not in line with each task, in which it requires a different level of difficulty according to students [15].

The results of this study prove that giving assignments requires other support. A study in Malaysia, learning styles practice contributed $39.20 \%$ to critical thinking skills [50]. Only a small part of reasoning tasks can support critical thinking skills. It takes a learning model that can support the learning styles of students by paying attention to environmental, emotional, physical and psychological factors of students.

The researchers only focused on contextual problems in the hope of getting meaningful learning $[12,13]$, and trying to get used to practicing problem-solving questions [11]. The results of the study are the same as previous research which shows that learning media that is packaged with contextual questions can foster students' critical thinking skills [51]. However, the task given is still not optimizing multimodal students. The assignments given were only in the form of text and images without color. It did not give a focus effect on students. It caused not all students to focus on learning. This is because with the use of multiple visual, audio, and audio-visual modalities, such as watching on a certain video recording can provide students with a focus on learning [16].

\section{Conclusions}

There are some limitations of the study as part of the 
conclusion. First, it is necessary to make many types of reasoning tasks to facilitate the diversity of students' abilities in order to achieve maximum learning achievements. Second, making reasoning tasks needs to pay attention to multimodal elements such as audio, visual or audio-visual in making tasks to achieve students' focus on doing the task. The third, this study only used one research method, while other types of research methods are needed to compare the results of the research. The researchers only measured cognitive achievement, whereas the application of tasks can measure metacognitive, procedural, and measure attitudes and creativity.

The results of the study using the students' understanding response questionnaire showed that the critical thinking activities through reasoning task in the understanding category are very good. The learning achievements of student cognitive achievement are able to exceed the minimum completeness criteria of learning achievements. Students' learning achievements of cognitive achievement are not able to achieve the classical completeness.

The results of this study can initiate further research on the basis that assignments containing contextual problems can contribute to critical thinking skills. Learning with digital media can optimize these findings with problem-based learning designs that still pay attention to student learning styles.

\section{Acknowledgments}

We are very grateful to experts for their appropriate and constructive suggestions to improve this template and to Indonesia Endowment Fund for Education.

\section{REFERENCES}

[1] Jeweet, S. Fisika Untuk Sains dan Teknik. (Salemba Teknika, 2010).

[2] Nasional, K. P. Undang-Undang Standar Pendidikan Nasional, 2003.

[3] Jurfri, W. Belajar dan Pembelajaran Sains, Rineka Cipta, Indoneia, 2013.

[4] Hamruni, Strategi Pembelajaran, Insan Madani, Indonesia, 2011.

[5] Azis, H., Marzuki, Y. \& Festiyed, Analisis E-Book Fisika SMA Kelas X Semester Ganjil, Pillar Of Physics Education, Vol.12, No.3, 593-600, 2019.

[6] Mochamad Irsyan, S., Setiawan, A. \& Rusnayati, H. Analisis Buku Ajar Fisika SMA Kelas X Di Kota Bandung Berdasarkan Komponen Literasi Sains, Prosidings Seminar Nasional Fisika, 94-102, 2013.
[7] McCrudden, M. T. \& Sparks, P. C, Exploring the effect of task instructions on topic beliefs and topic belief justifications: A mixed methods study, Contemp. Educ. Psychol, Vol. 39, No.1, 1-11, 2014.

[8] Taylor, F. Capitalizing on Language Learners' Individuality: From Premise to Practice Tammy Gregersen and Peter D. MacIntyre. Bristol, England, 2015

[9] Nunan, D. Task-based language teaching, Cambridge University Press, USA, 2004.

[10] Han, Y. \& McDonough, K. Motivation as individual differences and task conditions from a regulatory focus perspective: their effects on L2 Korean speech performance. Innov. Lang. Learn. Teach, Vol. 1, No. 1, 1-12, 2019.

[11] Bouffard, T., Boisvert, J., Vezeau, C., \& Larouche, C. The impact of goal orientation on self-regulation and performance among college students. Br. J. Educ. Psychol, Vol. 65, No. 1, 317-329, 1995.

[12] Skehan, P. A framework for the implementation of task-based instruction. Appl. Linguist, Vol. 17, No.1, 38-62, 1996.

[13] Stott, A. \& Hobden, P. Implementation challenges influencing the efficacy of group-work tasks that require inductive or deductive reasoning during physical sciences lessons. Journal of Education, Vol. 77, No. 1, 2019.

[14] Halici Page, M. \& Mede, E. Comparing task-based instruction and traditional instruction on task engagement and vocabulary development in secondary language education. J. Educ. Res, Vo. 111, No. 3, 371-381, 2018.

[15] Sun, J. \& Rao, N. Scaffolding interactions with preschool children: Comparisons between Chinese mothers and teachers across different tasks. Merrill-Palmer Quarterly, Vol. 58, No. 1, 110-140, 2012.

[16] Kannass, K. N., Colombo, J. \& Wyss, N. Now, pay attention! the effects of instruction on children's attention. ournal of Cognition and Development, Vol. 11, No. 4, 509-532, 2010.

[17] Ellis, R. Task-based language learning and teaching, Oxford University Press, USA, 2003.

[18] Magliano, J. P., Cohen, R., Allen, G. L. \& Rodrigue, J. R. The impact of a wayfinder's goal on learning a new environment: Different types of spatial knowledge as goals. Journal of Environmental Psychology, Vol, 15, No. 1, 65-75, 1995.

[19] Kaakinen, J. K. \& Hyönä, J. Perspective effects in repeated reading: An eye movement study, Memory and Cognition, Vol. 35, No. 6, 1323-1336, 2007.

[20] Arend, R. Learning to Teach: Belajar untuk Mengajar, Pustaka Pelajar, Indonesai, 2008.

[21] Beattie, D. K. The Rich Task: A Unit of Instruction and A Unit of Assessment. Art Education, Vol. 59, No. 6, 12-16, 2006.

[22] David Merrill, M. A task-centered instruction, Journal of Research on Technology in Education, Vol. 40, No. 1, 5-22, 2007.

[23] Gillier, T., Chaffois, C., Belkhouja, M., Roth, Y. \& Bayus, B. L. The effects of task instructions in crowdsourcing 
innovative ideas. ournal of Research on Technology in Education, Vo. 40, No. 1, 134, 35-44, 2018.

[24] Ghezzi, A., Gabelloni, D., Martini, A. \& Natalicchio, A. Crowdsourcing: A Review and Suggestions for Future Research, International Journal of Management Reviews, Vol. 20, No. 2, 343-363, 2018.

[25] Paulus, P. B., Kohn, N. W. \& Arditti, L. E. Effects of quantity and quality instructions on brainstorming, Journal of Creative Behavior, Vol. 45, No. 1, 38-46, 2011.

[26] Mackey, A. Input, interaction and second language development: An empirical study of question formation in ESL, Studies in Second Language Acquisition, Vol. 21, No. 1, 557-587, 1999.

[27] Ellis, R., Li, S. \& Zhu, Y. The effects of pre-task explicit instruction on the performance of a focused task, System, Vol. 80, No. 1, 38-47, 2019.

[28] Dackermann, T., Kroemer, L., Nuerk, H. C., Moeller, K. \& Huber, S. Influences of presentation format and task instruction on children's number line estimation. Cognitive Development, Vol. 47, No. 1, 53-62, 2018.

[29] Kim, M., Bednarz, R. \& Kim, J. The ability of young Korean children to use spatial representations. International Research in Geographical and Environmental Education, Vol. 21, No. 3, 261-277, 2012.

[30] Trilling, F. 21st Century skills: Learning for life in our times, John Wiley \& Sons, Ltd., The, USA, 2009.

[31] Paul, Richard; Elder, L. Critical Thinking Concepts \& Tools, Radiologic Technology, Vol. 85, No. 6, 69-79, 2014.

[32] Facione, P. A. Facione, Peter A. Critical Thinking: What It Is and Why It Counts, Measured Reasons LLC, USA, 2009.

[33] Ennis, R. H. A Logica 1 Basis for Measu ring Critic al Think ing Skills, Educational Leadership, 44-48, 1985.

[34] Halpern, D. F. Teaching for Critical Thinking: Helping College Students Develop the Skills and Dispositions of a Critical Thinker, Education, Vol. 80, No. 1, 69-75, 1999.

[35] Roberson, B. \& Franchini, B. Effective Task Design for the TBL Classroom, Journal on Excellence in College Teaching, Vol. 25, No. 1. 275-302, 2014.

[36] Wang, Y. et al. The nature of learning tasks and knowledge acquisition: The role of cognitive engagement in physical education, European Physical Education Review, Vol. 25, No. 2, 293-310, 2019.

[37] De la Cruz, J. A. Selecting Proportional Reasoning Tasks.
Assumpt, Assumption College, Vol. 69, No. 2, 14-18, 2013.

[38] Singh, P. Understanding the concepts of proportion and ratio among grade nine students in Malaysia. International Journal of Mathematical Education in Science and Technology, Vol. 31, No. 4, 579-599, 2000.

[39] Hamdani. Strategi Belajar Mengajar, Pustaka Pelajar, Indonesaia, 2011.

[40] Hamzah, U. M. N, Belajar dengan Pendekatan PAIKEM., Bumi Aksara, Indonesia, 2015.

[41] Kementerian Pendidikan dan Kebudayaan. Permendikbud Nomor 104, 2014.

[42] Anderson \& Krathwohl. A Taxonomy for Learning, Teaching and Assessing: a Revision of Bloom's Taxonomy of Educational Objective, Longman Publishing, USA, 2001.

[43] Suharsimi, A, Prosedur Penelitian: Suatu Pendekatan Praktik, Rineka Cipta, Indonesia, 2013.

[44] Sumarsono, J. FISIKA untuk SMA/MA, Departemen Pendidikan Nasional, Indonesai, 2012.

[45] Sa'dun, A, Instrumen Perangkat Pembelajaran, PT Remaja Rosda Karya, Indonesai, 2015.

[46] Ariyawati, Prasetyaning Astuti Mahayu, J. W. \& Prihatin, J. 1), 2) , 2). J, Pembelajaran dan Pendidik. Sains, Vol. 2, No. 1, 9-15, 2017.

[47] Sugiono. Metode Penelitian Kuantitatif, Kualitatif, dan R\&D, Alfa Beta, Indonesai, 2017.

[48] Alex, Kozulin; Boris, Gindis; Vladimir, S Ageyev; Suzanne, M. Vygotsky, Cultural Education Theory, Context, USA. 2020.

[49] Van de Pol, J., Volman, M., Oort, F. \& Beishuizen, J. The effects of scaffolding in the classroom: support contingency and student independent working time in relation to student achievement, task effort and appreciation of support. European Physical Education Review, Vol. 25, No. 2, 293-310, 2019.

[50] Mahmood, Mohd Sobri \& Othman, Mohamad Khairi. Learning Style Practices and Critical Thinking of Students in Malaysia. Universal Journal of Educational Research, Vol 8, No. 8, 3570-3578, 2020.

[51] Lestari, Nurdiyah. et al. Life Skill Integrated Science-PBL Module to Improve Critical Thinking Skills of Secondary School Students. Universal Journal of Educational Research, Vol 8, No. 7, 3085-3096, 2020. 